\title{
OBSERVATION ON THE INDUCED SPAWNING PRACTICES IN THE HATCHERIES OF RAJSHAHI DISTRICT OF BANGLADESH
}

\author{
Abdus Salam Bhuiyan* and Naima Aktar \\ Department of Zoology, Rajshahi University, Rajshahi-6205, Bangladesh \\ *Corresponding author
}

\begin{abstract}
An investigation was conducted during the period from March to December 2009 to investigate the induced spawning practices in 22 hatcheries of 6 Upazilas of Rajshahi District of Bangladesh. It was observed that, 6 native fish species viz. rui (Labeo rohita), catla (Catla catla), mrigal (Cirrhina mrigala), calibaush (Labeo calbasu), bata (Labeo bata), gonia (Labeo gonius) and six exotic fish species such as silver carp (Hypophthalmichthys moltrix), bighead carp (Aristichthys nobilis), grass carp (Ctenopharyngodon idella), common carp (Cyprinus carpio), Thai pangus (Pangasius sutchi), rajputi (Puntius gonionotus) were used in the surveyed hatcheries for induced spawning purpose. The average length limit was $41.70 \pm 13.02$ to $72.81 \pm 25.98$ $\mathrm{cm}$, average age limit was $1.96 \pm 0.75$ to $3.08 \pm 0.90$ years and average weight limit was $1.83 \pm 0.79$ to $7.54 \pm 3.92 \mathrm{~kg}$ of the brood fish. Two types of hormone injections like PG (pituitary gland) and HCG (human chorionic gonadotropin) were used for induced spawning. The rate of $1^{\text {st }}$ doses of injections of PG were from 1 to $4 \mathrm{mg} / \mathrm{kg}$ and HCG from 150 to 500 IU/kg and the rate of $2^{\text {nd }}$ doses of injections of PG for native and exotic species were from 4 to $8 \mathrm{mg} / \mathrm{kg}$ and 4 to $10 \mathrm{mg} / \mathrm{kg}$ respectively. The incubation period and hatching rate in different fish species varied from 10 to 72 hours and $55 \%$ to $80 \%$, respectively.
\end{abstract}

Key words: Induced spawning, inducing agents (PG and HCG), brood fishes, hatcheries.

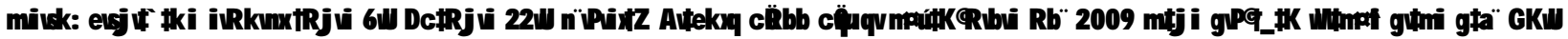

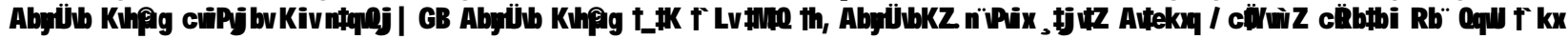
c B̈ wZ i gV thgb i "B (Labeo rohita), K V j v (Catla catla), g \$Mj (Cirrhina mrigala), K wi e Dm (Labeo calbasu), eWv (Labeo bata), Mvqv

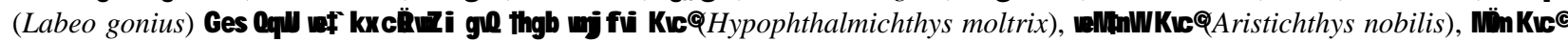

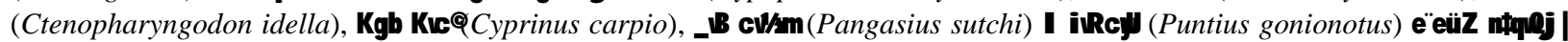

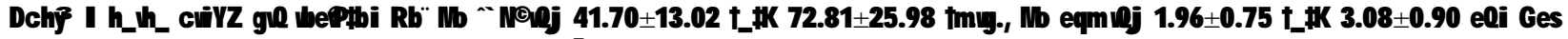

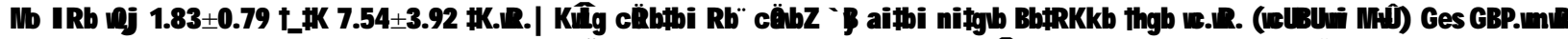

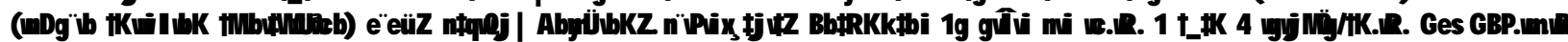

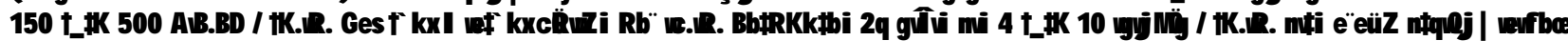

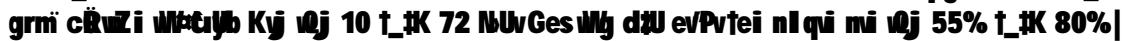

\section{Introduction}

Induced spawning refers to a process in which some stimulants, hormones or pituitary extracts are injected in the brood fishes, which do not spawn in the closed water bodies, causing the fishes to spawn (Bhuiyan et al. 2007). Induced spawning of local carps through hypophysation became a common practice in Bangladesh since 1967 (Ali, 1967). Meanwhile a large number of hatcheries in the private sector (estimated at over 700) have been established with the introduction of artificial breeding of exotic species (Ali, 1998). Induced spawning has opened the door of new era in the production of fish throughout the world. In Bangladesh, successful induced spawning was first done by Ali (1967) in carps through hypophysation having been standardized (Haque, 1975, Islam and Chowdhury, 1976; Ahmed, 1983 and Alam 1983).

The Department of Fisheries, Government of Bangladesh reported that a couple of years ago the number of government fish and prawn training farms were 6 , training academy 1 , fish hatcheries or fry production farms 112, bagda prawn hatcheries 2 and golda prawn hatcheries 17 (DoF 2009). Total fry production from government hatcheries in 2007-2008 was 7040 kg. In 20072008, the number of private fish hatcheries were 873 , fish nurseries 8712, bagda hatcheries 57, golda hatcheries 53 and the fry production from private hatcheries 4,16,946 kg in the country.

The annual fish spawn production from Rajshahi district of Bangladesh by the private hatcheries was $10,536 \mathrm{~kg}$ (DoF, 2009). The annual fish spawn production was 1.92 $\mathrm{kg}$, carp fry production $1.92 \mathrm{~kg}$, shorputi fry production $0.49 \mathrm{~kg}$, golda prawn juvenile production $0.15 \mathrm{~kg}$ and brood fish production was $1500 \mathrm{~kg}$ from Rajshahi district by the two public hatcheries (DoF 2009). Hatcheries therefore, play an important role for fish production. All government and non-government organizations should have more effective, ethical and planned activities to make artificial and induced spawning of fishes at grass-root levels (Hossain and Siddique, 2009). The present work was done 
with a view to knowing about the induced breeding techniques and practices in some selected hatcheries of Rajshahi in Bangladesh.

\section{Materials and Methods}

Data on induced spawning practices from 22 hatcheries under 6 Upazilas of Rajshahi District were collected during the period from March to December, 2009 (Table 1). Two public and 20 private hatcheries scattered over Paba, Puthia, Mohonpur, Durgapur, Bagmara and Bagha Upazilas were surveyed. For the study, a survey schedule was prepared and the data of induced spawning practices in the hatcheries were collected from the District and Upazila Fishery Offices by direct interview methods. The data were then scrutinized carefully, summarized and analyzed statistically.

Table 1. Name and addresses of the hatcheries under study in Rajshahi District.

\begin{tabular}{|l|l|l|}
\hline Hatcharies & Names & Locations in Upazilas \\
\hline $1^{*}$ & Rajshahi Matshow Beej Utpadon Khamar & Paba, Thana-Boalia \\
\hline 2 & Mashud Matshow Hatchery & Paba, Thana-Rajpara \\
\hline 3 & Anand Matshow Hatchery & Paba, Thana-Boalia \\
\hline 4 & Sarkar Matshow Hatchery & Paba, Thana-Rajpara \\
\hline $5^{*}$ & Puthia Matshow Beej Utpadon Khamar & Puthia \\
\hline 6 & Mullata Hatchery & Puthia \\
\hline 7 & Shuvo-Irin Matshow Prokolpo Hatchery & Puthia \\
\hline 8 & Atique Matshow Hatchery & Puthia \\
\hline 9 & Duivai Sonali Matshow Hatchery & Mohonpur \\
\hline 10 & Faisal Agro Fisheries & Mohonpur \\
\hline 11 & Merina Matshow Hatchery & Bagmara \\
\hline 12 & Bani Matshow Hatchery & Bagmara \\
\hline 13 & Bahi Bhai Matshow Hatchery & Bagmara \\
\hline 14 & Monika Hatchery & Bagmara \\
\hline 15 & Manchur Matshow Hatchery & Durgapur \\
\hline 16 & Amagachi Carp Hatchery & Durgapur \\
\hline 17 & Bhai Bon Matshow Hatchery & Durgapur \\
\hline 18 & Inni Matshow Prozonon Khamar & Durgapur \\
\hline 19 & Ibne Salam Matshow Hatchery & Durgapur \\
\hline 20 & Zahid Matshow Hatchery & Durgapur \\
\hline 21 & Sarker Matshow Hatchery & Durgapur \\
\hline 22 & Seba Agro Company Ltd. & Bagha \\
\hline Government hatcheries. & \\
\hline
\end{tabular}

\section{Results and Discussion}

Selection of brood fishes for spawning: According to the length, age and weight of the brood fishes, the appropriate species were selected in the hatcheries (Table 2). Length of the fishes varied around $42-73 \mathrm{~cm}$, age between 1.96 and 3.08 years and weight between 1.87 and $7.54 \mathrm{~kg}$. Khan (1943), Islam and Chowdhury (1976), Penman and McAndrew (1998) emphasized the role of proper species selection of brood fishes for successful induced spawning. The present results corroborate with those of Bhuiyan et al. (2008) who demonstrated that induced spawning of Labeo rohita was dependent on selecting healthy brood fishes.

Inducing agents for induced breeding: Mainly two types of inducing agents viz. pituitary gland (PG) and the human chorionic gonadotropin (HCG) were used in the hatcheries under survey. PG was used for all fishes except the silver and bighead carps where HCG was used. For the $1^{\text {st }}$ and $2^{\text {nd }}$ doses, PG of 1 to $4 \mathrm{mg} / \mathrm{kg}$ and $4-10 \mathrm{mg} / \mathrm{kg}$, respectively, were applied. On the other hand, 150-500 IU/kg HCG were applied only as the $1^{\text {st }}$ dose (Table 3). Fontenel (1955), Atz and Pickford (1959), Das and Khan (1962), Chaudhuri (1976), Crim and Evans (1976), Mirza et al. (1993), Verdia (1994) and Alam and Bhuiyan (1999) also adopted similar practices for induced breeding in various fishes. It was found that fishes with correct dose of hormone injection spawned under artificial condition and gave good results. According to Ahmed (1945) PG influenced the spawning of $L$. rohita. In agreement with the present doses Khan (1938), Alikunhi et al. (1960), Haque (1975), Chaudhuri (1977), Moitra and Sarker (1970), Khan et al. (1992), Mahanta et al. (1998) and Bhuiyan et al. (2008) used similar doses for induced spawning in common carps.

Incubation and hatching: The incubation period of different fish species was found to range between the minimum of 10 and the maximum of 72 hours and the rate of hatching in different hatcheries ranged between $55 \%$ and $80 \%$ (Fig. 1). These findings are similar to the observations of Alikunhi et al. (1964), Ali (1967) and Singh et al. (2000). 
Table 2. Species-, length-, age- and weight-wise selection of brood fishes for spawning in Rajshahi.

\begin{tabular}{|c|c|c|c|c|c|c|c|c|}
\hline \multirow[t]{2}{*}{ Type } & \multirow{2}{*}{$\begin{array}{l}\text { Common } \\
\text { names }\end{array}$} & \multirow[b]{2}{*}{ Scientific names } & \multicolumn{2}{|c|}{ Length $(\mathrm{cm})$} & \multicolumn{2}{|c|}{ Age (year) } & \multicolumn{2}{|c|}{ Weight (kg) } \\
\hline & & & Min & Max & Min & Max & Min & Max \\
\hline \multirow{6}{*}{ 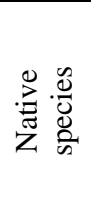 } & Rui & Labeo rohita & 45.72 & 76.2 & 2 & 3 & 2 & 8 \\
\hline & Catla & Catla catla & 63.5 & 88.9 & 3 & 5 & 3 & 15 \\
\hline & Mrigel & Cirrhina mrigala & 45.72 & 76.2 & 2 & 3 & 2 & 8 \\
\hline & Calibaush & Labeo calbasu & 30.48 & 50.8 & 2 & 3 & 2 & 5 \\
\hline & Bata & Labeo bata & 17.78 & 22.86 & 1 & 2 & 0.4 & 1 \\
\hline & Gonia & Labeo gonius & 45.72 & 96.52 & 1.5 & 3 & 1.5 & 10 \\
\hline \multirow{8}{*}{ 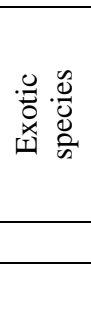 } & Silver carp & Hypopthalmicthys molitrix & 45.72 & 81.28 & 2 & 3 & 2 & 8 \\
\hline & Bighead carp & Aristichthys nobilis & 50.8 & 101.6 & 2 & 3 & 2 & 8 \\
\hline & Grass carp & Ctenopharyngodon idella & 50.8 & 88.9 & 3 & 4 & 3 & 7 \\
\hline & Common carp & Cyprinus carpio & 40.64 & 63.5 & 3 & 4 & 2 & 7 \\
\hline & Thai pangus & Pangasius sutchi & 43.18 & 96.52 & 1 & 2 & 1.5 & 12 \\
\hline & Rajputi & Puntius gonionotus & 20.32 & 30.48 & 1 & 2 & 0.5 & 1.5 \\
\hline & Total & & 500.38 & 873.76 & 23.5 & 37 & 21.9 & 90.5 \\
\hline & Mean \pm SD & & $\begin{array}{c}41.70 \pm \\
13.02\end{array}$ & $\begin{array}{c}72.81 \pm \\
25.98\end{array}$ & $\begin{array}{c}1.96 \pm \\
0.75\end{array}$ & $\begin{array}{c}3.08 \pm \\
0.90\end{array}$ & $\begin{array}{c}1.83 \pm \\
0.79\end{array}$ & $\begin{array}{c}7.54 \pm \\
3.92\end{array}$ \\
\hline
\end{tabular}

Table 3. Hormonal doses used in different brood fishes for induced spawning in Rajshahi.

\begin{tabular}{|c|c|c|c|c|}
\hline \multirow{2}{*}{$\begin{array}{c}\text { Common names of } \\
\text { fishes }\end{array}$} & $1^{\text {st }}$ doses of PG (mg/kg) and HCG (IU/kg) & \multicolumn{2}{c|}{$2^{\text {nd }}$ doses of PG (mg/kg) } \\
\cline { 2 - 5 } & Minimum & Maximum & Minimum & Maximum \\
\hline Rui & 1.25 & 2.5 & 5 & 8 \\
\hline Catla & 1.25 & 3 & 5 & 8 \\
\hline Mrigel & 1 & 3 & 4 & 8 \\
\hline Calibaush & 1 & 3 & 4 & 8 \\
\hline Bata & 1 & 4 & 6 & 8 \\
\hline Gonia & 1 & 3 & 6 & \\
\hline Silver carp & $150^{*}$ & $500^{*}$ & 4 & 9 \\
\hline Bighead carp & $150^{*}$ & $500^{*}$ & 4 & 8 \\
\hline Grass carp & 1 & 3 & 6 & 8 \\
\hline Common carp & 1 & 3 & 4 & 10 \\
\hline Thai pangus & 2 & 2 & & 8 \\
\hline Rajputi & 1 & 4 & & \\
\hline
\end{tabular}

PG = pituitary gland; HCG = Human chorionic gonadotropin; *values for HCG doses only.

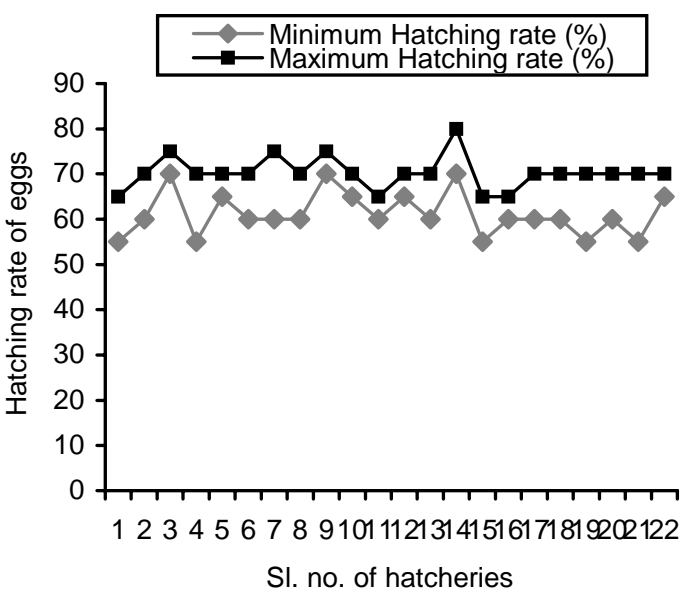

Fig. 1. Hatching rates of eggs in different hatcheries under study.

\section{Conclusion}

Six native and six exotic fish species were used by the surveyed hatcheries for induced spawning. The average length of the brood fishes was 41.70 \pm 13.02 to $72.81 \pm 25.98 \mathrm{~cm}$, age $1.96 \pm 0.75$ to $3.08 \pm 0.90$ years and weight $1.83 \pm 0.79$ to $7.54 \pm 3.92 \mathrm{~kg}$ in which PG and HCG were used. The $1^{\text {st }}$ doses of PG varied from 1 to 4 $\mathrm{mg} / \mathrm{kg}$ but the $2^{\text {nd }}$ doses ranged between 4 to $8 \mathrm{mg} / \mathrm{kg}$ and 4 to $10 \mathrm{mg} / \mathrm{kg}$ for the native and exotic species. Whereas only the $1^{\text {st }}$ dose of HCG is used for exotic species, that varied between 150 and $500 \mathrm{IU} / \mathrm{kg}$. The hatching rate of the studies fishes ranged between 55\% and $80 \%$. The present study thus gives a brief account of induced spawning practices in 22 hatcheries from 6 Upazilas in Rajshahi District of Bangladesh. 
Acknowledgements: This forms a part of M.Sc. thesis by the junior author. The authors are thankful to $\mathrm{Mr}$. M.I. Golder, DFO of Rajshahi for extending his cordial cooperation. The authors are also grateful to the owners, operators and staffs of the surveyed hatcheries to supply data and information related to the hatcheries.

\section{References}

Ahmed MK. 1983. Induced breeding of Indian major carps, Chinese carps and catfish. Freshwater Fish Research Station Chandpur, Bangladesh. pp. 44-52.

Ahmed N. 1945. Factors influencing the spawning of Indian carps. Symposium of the "Factors influencing the spawning of Indian carps". Proc. Nat. Inst. Sci. India. 11(3): p. 329.

Alam AKMA. 1983. Low cost hatchery. Adam News 10(L): 27-33.

Alam MM and Bhuiyan AS. 1999. Determination of the optimum PG dose for induced spawning of Labeo rohita (Hamilton, 1822). Univ. j. zool. Rajshahi Univ. 18: 103-108.

Ali MH. 1967. Induced breeding of major carps in ponds by pituitary hormone injection, Agric. Inform. Serv. Dhaka, pp. 23-26.

Ali ML. 1998. Fishery resources development and management technique. Fish week 98 compendium. Department of Fisheries, Ministry of Fisheries and Livestock, Government of the Peoples Republic of Bangladesh, Dhaka, pp. 1-10.

Alikunhi KH, Sukumaran KK, Parameswaran S and Banerjee SC. 1964. Preliminary observations on commercial breeding of Indian carps under controlled temperature in the laboratory. Bull. Cent. Ind. Fish. Res. Inst. Barrackpore. 3: 20.

Alikunhi KH, Vijayalakshman MA and Ibrahim KH. 1960. Preliminary observation on the spawning on Indian carps, induced by injection of pituitary hormone. Ind. $J$. Fish. 7(1): 1-19.

Atz JW and Pickford GE. 1959. The use of pituitary hormones in fish culture. Endeavour. 18(71): 125-129.

Bhuiyan AS, Islam MK and Tanjeena Z. 2007. Induced spawning of Puntius gonionotus (Bleeker). Bangladesh J. Zool. 35(2): 245-249.

Bhuiyan AS, Musa ASM and Islam MK. 2008. Some observations on the induced spawning of Labeo rohita (Hamilton; 1822 ) by pituitary hormone injection. Bangladesh. J. Life Sci. 20(1): 89-94.

Chaudhuri H. 1976. Uses of hormones in induced spawning of carps. J. Fish. Res. Board. Can. 33: 940-947.

Chaudhuri H. 1977. Experiments on induced spawning of Indian carps with pituitary injections. Ind. J. Fish. 7(11): 20-24.

Crim LW and Evans DN. 1976. Gonadotropic hormone treatment of rainbow trout (Salmo gairdneri) Plasma hormone profile following a single injection. J. Fish. Res. Board Can. 33: 2841-2844.

Das SM and Khan HA. 1962. The pituitary and pisciculture in India with an account of the pituitary of some Indian fishes and review of techniques and literature on the subject. Icthyobiologica 1: 43-58.

DoF (Department of Fisheries) 2009. Fishery wealth of Bangladesh(in Bengali). Jatio matshow shaptaho, 2009 (Shonkolon), Department of Fisheries, Ministry of Fisheries and Livestock, Govt. of People's Republic of Bangladesh. pp. 105-111.

Fontenel O. 1955. Injecting pituitary (hypophyseal) hormones into fish to induce spawning. Prog. Fish. Cult. 17(2): 71-75.

Haque KA. 1975. Some observations on the induced spawning of major carps by pituitary hormone injection. Freshwater fish. Res. Sta. Chandpur. Bull. 1: 19-33.

Hossain DG and Siddiqui AB. 2009. Present status of hatcheries and fish production of Rajshahi. BSS, Rajshahi, Bangladesh. p. 2.

Islam MZ and Chowdhury AQ. 1976. Induced spawning of major carps for commercial production of fry for fish seed in Bangladesh. Bangladesh J. Zool. 4(2): 51-61.

Khan H. 1938. Ovulation in fish (Effect of administration of anterior lobe of pituitary gland). Curr. Sci. 7(5): 233-234.

Khan HA. 1943. Observation on the spawning behaviour of carps in Panjab. Proc. Nat. Inst. Sci. India 11(3): 315-320.

Khan HA, Gupta SD and Tantia MS. 1992. A new method to induced spermiation, ovulation and spawning by hypophysation in the Indian major carp Labeo rohita. J. Aquacult. Trop. 7(2): 143-150.

Mahanta PC, Rao KG and Pandev AK. 1998. Induced spawning of an Indian major carp, Labeo rohita in the same breeding season under theagroclimatic conditions of Assam. J. Adv. Zool. 19(2): 99-101.

Mirza ZS, Naik IU and Bhatti MZ. 1993. Induced spawning of Indian major carps using carp pituitary homogenate and human chorionic gonadotropin in the Punjab (Pakistan). Proc. Pak. Cong. Zool. 12: 423-428.

Moitra SK and Sarker SK. 1978. On the potency of the pituitary gland extract in relation to spawning in an Indian fresh water carp. Cirrhina mrigala (Ham.) Zool. Anz. Jena. Zool. 314: 275-282.

Penman DJ and McAndrew BW. 1998. Practical aspects of selection and fitness of stocked fish. FAO-FisheriesTechnical-Paper No. 374: 223-233.

Singh BN, Das RC, Sahu AK. and Pandey AK. 2000. Balanced diet for the brood stock of Catla catla and Labeo rohita and induced breeding performance using ovaprim. $J$. Adv. Zool. 21(2): 92-97.

Verdia HK. 1994. Advancement of maturity with HCG in Indian major carps. J. Aquat. Biol. Fish. 1(1): 1922.

Manuscript received on 17 November 2010 and revised on 15 December 2010 